\title{
INDEX TO VOLUME XII
}

\section{A}

$\bar{a}$ compensatorily lengthened in Sinhalese, $163-5$.

- a final in Hruso, 186.

AbBotr (NaBLa), Two Queens of Baghdad, $427 \mathrm{f}$.

ABDणL AzIz, The Mansabdàri System and the Mughul Army, 473.

Abdul Rahaman, the Samieśa Rāsaka of, $462 \mathrm{f}$.

Abel (Theodora E.), trans., Ta'limm al muta'allim-Tarīg al-ta'allum, 429.

Account of the Târikhi Qumm, An (Ann K. S. Lambton), 586-596.

Admonitions and Inseriptions in Chinese prose, 784.

Adventurers in Siam in the Seventeenth Century (E. W. Hutchinson), $469 \mathrm{f}$.

African place-names on maps, the spelling of, 824-830.

Ahmedî, notes on, 537-541.

AJibolaA (J. 0.), Orin Yoruba, 486 f. ; Ounje ile Yoruba, $486 \mathrm{f}$. ; Owe Yoruba, $486 \mathrm{f}$.

AldRICH (HaRry S.), A Topical Chinese Dictionary, $479 \mathrm{f}$.

Annual Bibliography of Indian History and Indology, Vol. 3 (Braz A. Fernandes), 462.

Another Catalogue of the Kanjur (Armold Kunst), 106-121.

A propos d'un sens magico-religieux de skt. guru- (J. Gonda), 124-131.

Arabic Reader (Chaim Rabin), 438.

Arab Poet and Arabic Philologist (H. A. R. Gibb), 574-8.

arämpät, 67.

ArberRx (A. J.), The Miracle of the Pearls, 36-8; Notes on the Mahäsin al-majälis of Ibn al-AArif, 524-532 ; edit., Pages from the Kitāb al Luma', 428 ; rev., $445 \mathrm{f}$.

Articulation, word-palatograms and, 857-864. Al-'Arüd al-Sahl (I. M. Husaini and F. A. Al-Ghūi), $241 \mathrm{f}$.

Arzurri, genesis of the, $81 \mathrm{f}$; where found, looks and dress of, $82 \mathrm{f}$.; appearance and behaviour towards man, $83 \mathrm{f}$.; female form of, $84 \mathrm{f}$.

asuk, 67.

Avestan, 329-332.

Arvai of the Sangam Anthologies, The (M. S. H. Thompson), 399-402.

\section{B}

Bacot (Jacquas), Grammaire du Tibétain Littéraire, 450-3.

Battey (H. W.), Irano-Indica, 319-332 ; edit., Khotanese Texts, I, 453-7; The Seven Princes, 616-624.

Bantoe-Filosofie (P. Placied Tempels), $267 \mathrm{f}$.
Bantu languages, gender, number and person in, 847-856.

Bantu. Modern Grammatical, Phonetical, and Lexicographical Studies since 1860 (Clement M. Doke), 486.

Baptême de Feu, Le (C. M. Edsman), 234.

Barnett, Dr. L. D., bibliography of the published writings of, 497-523.

BARNETT (L. D.), rev., 249-253, $258 \mathrm{f}$.

Barskhan, 290-4, 297, 305.

BASHAM (A. S.), Harșa of Kashmir and the Iconoclast Ascetics, 688-691.

Bashshär ibn Burd ('Umar Farrūkh), $238 \mathrm{f}$.

Beginner's Chinese-English Dictionary of the National Language (Gwoyeu), $A$ (W. Simon), $481 \mathrm{f}$.

Belvalkar (S. K.), edit., Bhismaparvan, Part I, 459; trans., The Bhagavadgītä, $459 \mathrm{f}$., $460 \mathrm{f}$.

Benzing (Jorannes), "The Forest-Demon." A Tatar Poem of Gabdulla Tuqaj, 73-85.

Bercher (LGoN), Lexique Arabe-Français, $242 \mathrm{f}$.

Bernard (Solange), trans., Contes Populaires Inédits du Cambodge, $259 \mathrm{f}$.

BerRy (J.), A Gã Folk Tale, 409-416.

Bhagavadgit ā, The (edit., Shripad Krishna Belvalkar), 459 f. ; (trans., Shripad Krishna Belvalkar), $460 \mathrm{f}$.

Bhavadeva BHatTa, The Tautätitamatatilaka, Part III (edit., A. Chinnaswami Sastri and Pattabhirama Shastri), 462.

Bhayani (HartvallabH), edit., The Samdésa Räsaka of Abdul Rahaman, $462 \mathrm{f}$.

Bhismaparvan, Part I (edit., S. K. Belvalkar), 459.

Bibliography of the Published Writings of Dr. L. D. Barnett (Edith M. White), $497-523$.

Bih 比' = Wey 雼' ? (Walter Simon), 789-802.

Biographies and biographical notices in Chinese prose, $780 \mathrm{f}$.

BLOCH (JULES), Structure Grammaticale des Langues Dravidiennes, 253-5.

Body and External Life, The (Carl-Martin Edsman), $432 \mathrm{f}$.

Book of al-muhtassib (Nihāyat al-rutba fī talab al-hisba), (edit., Al-Sayed al Baz Al-"Arini), 434.

Bose (S. M.), The Working Constitution in India, $470 \mathrm{f}$.

Bou-Mergoud, Le: Folklore Tunisien (M. I. Dubouloz-Laffin), $\mathbf{4 3 3} \mathrm{f}$.

Bousquet (G. H.), L'Islam Maghrebin, 243.

Brovar (JoHN), Legends of Khotan and Nepal, 333-9; Lilätilaka: A Sanskrit Tract on Malayalam Grammar and Poetics, 148-162; Nepalese Buddhist Rituals, 668-676 ; rev., 467.

Brown (C. C.), A Malay Herodotus, 730-6.

Burmese-English Dictionary, $A$ (C. W. Dunn and J. A. Stewart), $258 \mathrm{f}$. 
Burmese Literature, Country Life in (C. W. Dunn, Hla Pe, and J. A. Stewart), 703-712.

Burmese word-palatograms and articulation, $862 \mathrm{f}$.

BurRow (T.), Dravidian Studies VI, 132-147 ; VII, 365-396 ; Sanskrit rájas, 645-65l; rev., $253-5,466 \mathrm{f}$,

Burssens (A.), Manuel de Tshiluba (Kasayi, Congo Belge), 485.

\section{C}

Carnochan (J.), A Study in the Phonology of an Igbo Speaker, 417-426.

Carra de Vaux (Baron), Tubleau des Racines Sémitiques (Arabe-Hébreu), 242.

Caste in India (J. H. Hutton), 245-8.

CatohPole (Captain H.), Elementary Urdu, General and Military, 253.

Cerimoniale per $i$ Missionari del Giappone, Il (Father Joseph Schütte), 482-4.

Снао (T. C.), Chinese Conversation in the National Language, 477.

Chinese Conversation in the National Language ('I. C. Chao), 477.

Chinese prose, a classified guide to the thirteen classes of, 770-788.

Chinese Sentence Series, Parts II and III (W. Simon and C. H. Lu), 477.

Chinese word-palatograms and articulation, $863 \mathrm{f}$.

Chinnaswami Sastri (A.), edit., The Tautatitamatatilaka of Bhavadeva Bhatta, Part III, 462.

Chintamani (Sir C. Y.), India's Constitution at Work, $470 \mathrm{f}$.

Chios, an eye-witness account of the expedition of the Florentines against, in $1599,542-554$.

Choksey (R. D.), Economic History of the Bombay Deccan and Karnatak (1818-1868), $473 \mathrm{f}$.; ed., Selections from the Deccan Commissioner's Files (Peshwa Daftar), Period of Transition (1818-1826) 474.

çiçri, 70.

Cinco Poetas Musulmanes (E. Garcfa Gómez), $236 \mathrm{f}$.

çkam, $71 \mathrm{f}$.

Classified Guide to the Thirteen Classes of Chinese Prose, A (E. D. Edwards), 770-788.

Clive in the English Political World, 176I-4 (C. H. Philips), 695-702.

Compositions presented at parting in Chinese prose, 777.

Connaissance. Revue de culture franco-arabe. Nos. 1 and 2, $243 \mathrm{f}$.

Contes Kabyles (E. Dermenghem), $428 \mathrm{f}$.

Contes Populaires Inédits du Cambodge (trans., François Martini and Solange Bernard), 259.

Context of the Yüan Tao and the Yüan Hsing, The (J. K. Rideout), 403-408.

Coptic Texts in the University of Michigan Collection (edit., William H. Worrell), $262-6$.

Cortesão (Armando), edit., The Suma Oriental of Tomé Pires and the Book of Francisco Rodrigues, $256 \mathrm{f}$.

Conx (Hans), Customary Law of the Haya Tribe, Tanganyika Territory, $484 \mathrm{f}$.
Country Life in Burmese Literature (C. W. Dunn, Hla Pe, and J. A. Stewart), 703712.

CresL (H. G.), Newspaper Chinese by the Inductive Method, 260 f.; Translations of Text Selections and Exercises in Newspaper Chinese, 261.

$c / s$ initial, loss of in South Dravidian, 132147.

Cultural History from the Vāyu Purāna (Devendrakumar Rajaram Patil), $457 \mathrm{f}$.

CUNY (A.), Recherches sur le Vocalisme, le Consonantisme, et la Formation des Racines en "Nostratique", 243.

Curia Muria, position of the dialect of, in modern South Arabic, 5-19.

Customary Law of the Haya Tribe, Tanganyika Territory (Hans Cory and M. M. Hartnel), $484 \mathrm{f}$.

\section{D}

Danikus (F. J.), Japanese Prose, 261 ; The Vocabulary of the Japanese Ports Lingo, 805-823.

Daniels (ОTоME), Dictionary of Japanese Sösho Writing Forms, $261 \mathrm{f}$.

Darab (GH. H.), trans., Makhzanol Asrār, 441-5.

Dardic, Niya documents and, 332.

Date of the Sogdian Ancient Letters, The (W. B. Henning), 601-615.

Daube (David), Studies in Biblical Law, 438-440.

Davies (C. Colsin), rev., $471 \mathrm{f}$.

Dermenghem (E.), Contes Kabyles, $428 \mathrm{f}$.

Desar (Mahadev), Maulana Abul Kalam Azad, 471.

DeY (H. L.), edit., Economic Problems of Modern India, Vol. II, 470.

Dharma-samuccaya: Compendium de la Loi. lre partie (trans., Lin Li-kouang), 446-450.

Dictionary of Japanese Sōsho Writing Forms (Otome Daniels), $261 \mathrm{f}$.

Dictionary of Standard Malay, A (MalayEnglish) (V. E. Hendershot and W. G. Shellabear), $476 \mathrm{f}$.

Doke (Clement M.), Bantu. Modern Grammatical, Phonetical, and Lexicographical Studies since 1860, 486.

Dravidian Studies (T. Burrow), VI, 132-147 ; VII, 365-396.

Dubouloz-Laffin (M. L.), Le Bou-Mergoud : Folklore Tunisien, $433 \mathrm{f}$.

Duns (C. J.), rev., 482-4.

DuNN (C. W.), A Burmese-English Dictionary, Part I, $258 \mathrm{f}$. ; Country Life in Burmese Literature, 703-712.

\section{$\mathbf{E}$}

$\bar{e}$ compensatorily lengthened in Sinhalese, 167.

$-e$ final in Hruso, $187 \mathrm{f}$.

Economic History of the Bombay Deccan and Karnatak (1818-1868) (R. D. Choksey), $473 \mathrm{f}$.

Economic Problems of Modern India, Vol. II (edit., Radhakamal Mukerjee and H. L. Dey), 470. 
Edgerton (Franklin), edit., The Sabhaparvan, $458 \mathrm{f}$.

Edicts and orders in Chinese prose, 777-780.

Edsman (C. M.), Le Baptême de Feu, 234 f. ; The Body and External Life, $432 \mathrm{f}$.

Edwards (E. D.), A Classified Guide to the Thirteen Classes of Chinese Prose, 770-788.

Efik, verbal tone patterns in, $832,835 \mathrm{f}$.

Elegies and orations for funerals and sacrifices in Chinese prose, $786-8$.

Elementary Urdu, General and Military (Captain H. Catchpole), 253.

Emeneau (M. B.), Kota Texts, $464 \mathrm{f}$.

-ëndè(h), Parthian ending, 58-65.

English Records of Maratha History. Poona Residency Correspondence, Vols. 8, 9, 11 (edit., Sir Jadunath Sarkar, Maharaj Kumar Raghubir Sinh and Nirod Bhushan Roy), $471 \mathrm{f}$.

Fnglish word-palatograms and articulations, 862.

entwe, 71.

Epitaphs in Chinese prose, 781-3.

Eragassa = Erakaccha = Erach, $122 \mathrm{f}$.

Essays in Chinese prose, $771 \mathrm{f}$.

Eulogies in Chinese prose, $784 \mathrm{f}$.

Ewe, verbal tone patterns in, $833 \mathrm{f}$.

Eye-witness Account of the Expedition of the Florentines against Chios in 1599, An (Jacob Loveen), 542-554.

\section{F}

Familie bei den Heutigen Beduinen Arabiens und seiner Randgebiete, Die (J. Henninger), 235.

Far East Must be Understood, The (H. van Straelen), 478.

FarRūkh ('UMAR), Bashshär ibn Burd, $238 \mathrm{f}$.; Hakim al-Ma'arra, 239 ; Ibn Bajja (Avem. pace) and the Philosophy in the Moslem West, 239 f. ; Ibn Tufail, 428 ; Ikhwãn us-Safã, 238; Nahwa at-ta'āwun al-'arabi, 241; Al-tasawwuf fi'l-Islām, $429 \mathrm{f}$.

Fernandes (Braz A.), Annual Bibliography of Indian History and Indology, Vol. III, 462.

Fijian, a study in the phonetics of, 737-752.

Frrth (J. R.), Word-Palatograms and Articulation, 857-864.

Fîrūzäbādī's "Wine-List" (A. S. Fulton), $579-585$.

FitzGerald (S. G. Vesey-), The Succession of Cognate Collaterals in Hindu Law, $677-687$; rev., $245-8,438-440$.

FJorentines, an eye-witness account of the expedition of the, against Chios in 1599 , $542-554$.

Foreign Sounds in Swahili (A. N. Tucker), 214-232.

"Forest-Demon, The." A Tatar poem of Gabdulla Tuqaj, 73-85 ; literary history of, 85.

Foster (Sir WILliam), edit., The Voyage of Sir Henry Middleton to the Moluccas, $1604-6,476$.

Frankmont (H. and H. A.), The Intellectual Adventure of Ancient Man, $431 \mathrm{f}$.
Fuchs (Walter), Der Jesuiten-Atlas der Kanghsi-Zeit: seine Entstehungsgeschichte nebst Namensindices für die Karten der Mandjurei, Mongolei, Ostturkestan und Tibet, 480 f.; The "Mongol Atlas" of China, $478 \mathrm{f}$

Fulton (A. S.), Fīrūzābādī's "Wine-List", $579-585$.

G

Gã Folk Tale, A (J. Berry), 409-416.

Gafat Documents (Wolf Leslau), $266 \mathrm{f}$.

Gai (Govind Swamirao), Historical Grammar of Old Kannada, $466 \mathrm{f}$.

Gardizi on India (V. Minorsky), 625-640.

Gender, Number, and Person in Bantu Languages (Malcolm Guthrie), 847-856.

Gershevitch (Ilyy), rev., 244.

Al-Ghazäli the Mystic (Margaret Smith), 237.

Ghoshal (U. N.), A History of Hindu Public Life. Part I, 249.

Al-Ghūl (F. A.), Al-'Arūd al-Sahl, 241 f.

Gibs (H. A. R.), Arab Poet and Arabic Philologist, 574-8.

Giles (L.), A Tibeto-Chinese Word-andPhrase Book, 753-769; rev., 477-482.

Gilgamesh Epic and Old Testament Parallels, The (A. Heidel), 436.

Gómez (E. Garcì), Cinco Poetas Musulmanes, $236 \mathrm{f}$.

Gonda (J.), A propos d'un sens magicoreligieux de skt. guru-, 124-131.

Grammaire du Tibétain Littéraire (Jacques Bacot), 450-3.

Grammatica di Persiano Moderno, con Esercizi, Vocabolarietti e Note di Metrica (Ettore Rossi), 445.

Green (M. M.), The Unwritten Literature of the Igbo-Speaking People of South-Eastern Nigeria, 838-846.

Grunebaum (G. E. von), Medieval Islam, 430 f. ; trans., Ta'lim al muta'allim-Tarìg al-táallum, 429.

GUNN (BATTISCOMBe), rev., $262 \mathrm{f}$.

guru-, $\bar{A}$ propos d'un sens magico-religieux de skt., 124-131.

GUThrie (Malcolm), Gender, Number and Person in Bantu Languages, 847-856; rev., $484 \mathrm{f}$.

H

Hakīm al-Ma'arra ('Umar Farmūkh), 239.

Hakluyt, Richard, and his Successors, $257 \mathrm{f}$.

Handbook of Japanese Grammar (Harold Henderson), 262.

Harff, Arnold von, The Pilgrimage of, 436.

HARRISON (J. B.), rev., 472-4.

Harsa of Kashmir and the Iconoclast Ascetics (A. L. Basham), 688-691.

Hartines (M. M.), Customary Law of the Haya Tribe, Tanganyika Territory, $484 \mathrm{f}$.

Hartog, Sir Phinip, obituary of, 491-3.

HeIDEL (A.), The Gilgamesh Epic and old Testament Parallels, 436.

Henderson (Evatenie, J. A.), Notes on the Syllable Structure of Lushai, 713-725. 
Henderson (HaRoLd), Handbook of Japanese Grammar, 262.

HENDERSHOT (V. E.), A Dictionary of Standard Malay (Malay-English), $476 \mathrm{f}$.

Henning (W. B.), The Date of the Sogdian Ancient Letters, 601-615; A Sogdian Fragment of the Manichaean Cosmogony, 306-318; Sogdica, 244 ; Two Manichaean Magical Texts with an Excursus on the Parthian ending $-\bar{e} n d \bar{e} h, 39-66$.

Henninger (J.), Die Familie bei den Heutigen Beduinen Arabiens und seiner Randgebiete, 235.

Heritage of Karnātaka, The (R. S. Mugali), $255 \mathrm{f}$.

Highways and Byways of Literary Criticism in Sanscrit (S. Kuppuswami Sastri), $250 \mathrm{f}$.

Hill Tribes of Jeypore, The (Lakshmi Narayana Sahu), 251.

Hindu Law, the succession of cognate collaterals in, 677-687.

Historical Grammar of Old Kannada (Govind Swamirao Gai), $466 \mathrm{f}$.

History of Hindu Public Life, A. Part I (U. N. Ghoshal), 249.

HeA Pe, Country Life in Burmese Literature, 703-712.

Homily on the Nativity of our Lord by Severian, Bishop of Gabala (Cyril Moss), $555-566$.

HoNY (H. C.), A Turkish-English Dictionary, 440.

Hruso (Robert Shafer), 184-196 ; dialect divergence in, $185 \mathrm{f}$. ; final nasals in, $189 \mathrm{f}$. ; phonetics, 186; phonetic correspondences in, 185 ; prefixes in, 185.

Hsaune, U, 705.

Husatni (I. M.), Al-'Arüd al-Sahl, 241 f.]

Hutchinson (E. W.), Adventurers in Siam in the Seventeenth Century, $469 \mathrm{f}$.

HuTtoN (J. H.), Caste in India, 245-8.

I

$\bar{i}$ compensatorily lengthened in Sinhalese, $165 \mathrm{f}$.

$-i$ final in Hruso, 187.

Ibn al-Arif, notes on the Mahäsin al-majälis of, 524-532.

Ibn Bajja (Avempace) and the Philosophy in the Moslem West ('Umar Farrūkh), 239 f.

Ibn Tufail (Omar A. Farrukh), 428.

Igbo speaker, a study in the phonology of an, 417-426.

Igbo-speaking people of South-Eastern Nigeria, the unwritten literature of the, 838-846.

Igbo, verbal tone patterns in, $832 \mathrm{f}$., $836 \mathrm{f}$.

Ikhwān us-Safā ("Umar Farrūkh), 238.

Ilera li ögùn ord (J. S. Ogunlesi), 486 f.

IMPERIAL RECORD DEPARTMENT, GOVERNMENT of INDis, The Indian Archives, Vol. I, no. $1,467$.

India and Democracy (Sir George Schuster and Guy Wint), 468.

India, Beginnings of Ismā'ilism in, $599 \mathrm{f}$.

Indian Archives, The, Vol. I, no. 1, 467.

India's Constitution at Work (Sir C. Y. Chintamani and M. R. Masani), $470 \mathrm{f}$.

Indo-Arica, II (R. L. Turner), 64l-4.
Indo-Aryan and Dravidian, III (Alfred Master), 340-364.

Intellectual Adventure of Ancient Man, The (H. and H. A. Frankfort, J. A. Wilson, T. Jacobsen, W. A. Irwin), 431 f.

Introduction à l'Élude des Anciens Codes Orientaux (J. Leroy), 234.

Introduction to Telugu Grammar, $A n$ (Alfred Master), 466.

Iqbal, His Art and Thought ('Abdul Vähid), $445 \mathrm{f}$.

Irano-Indica (H. W. Bailey), 319-332.

Iron and the plough in early China, note on, $803 \mathrm{f}$.

IRwIN (W. A.), The Intellectual Adventure of Ancient Man, $431 \mathrm{f}$.

Al-Istām 'alà muftariq al-Turuq (L. Weiss), $434 \mathrm{f}$.

Islam and Christian Theology. Part 1, Vol. I (J. Windrow Sweetman), 435.

L'Islam Maghrebin (G. H. Bousquet), 243.

Ismā'īili Notes (B. Lewis), 597-600.

Ismāî̀lī oath formula from Mamlūk Egypt, an, $597 \mathrm{f}$.

Ismā'ilism in India, beginnings of, $599 \mathrm{f}$.

\section{$\mathbf{J}$}

Jacobsen (T.), The Intellectual Adventure of Ancient Man, $431 \mathrm{f}$.

Japanese ports lingo, vocabulary of the; 805-823.

Japanese Prose (F. J. Daniels), 261 f.

Jesuiten-Allas der Kanghsi-Zeit: seine Entstehungsgeschichte nebst Namensindices für die Karten der Mandjurei, Mongolei, Ostturkestan und Tibet, Der (Walter Fuchs), $480 \mathrm{f}$.

Jina ViJAYA (ŚRI MuNI), edit., The Samdeśa Rāsaka of Abdul Rahaman, $462 \mathrm{f}$.

Jog-Bāshisht, A Note on an Illustrated Manuscript of the (J. V. S. Wilkinson), 692-4.

\section{$\mathbf{K}$}

$-k$ final in Hruso, 188.

KalF (S. I.), T'ibi t'ire, $486 \mathrm{f}$.

Kanjur, another catalogue of the, 106-121.

Kautalya Studies (Sten Konow), 249 f.

Khotan and Nepal, legends of, 333-9.

Khotanese, 329-331.

Khotanese, Avestan and Ossetic, 329-332.

Khotanese Texts, I (edit., H. W. Bailey), 453-7.

Kitäb al-Luma', Pages from the, 428.

$k n a ̈ s w, 67$.

Konow (STEN), Kautalya Studies, $249 \mathrm{f}$.

Koppers (WILhelm), Probleme der Indischen Religionsgeschichte, $251 \mathrm{f}$.

Kota Texts (M. B. Emeneau), $464 \mathrm{f}$.

krāke, 68.

ksuna, $328 \mathrm{f}$.

Ku, Sadainghmut U, $707 \mathrm{f}$.

Kui, syncope and aphæresis with compensation in, 340-6.

Kui-Kuvi, 357-362.

Kunst (ARNold), Another Catalogue of the Kanjur, 106-121. 
KUPPUSwami Sastri (S.), Highways and By. ways of Literary Criticism in Sanscrit, $250 \mathrm{f}$.

K×1, U, 704.f.

\section{L}

-l final in Hruso, 190.

Lambton (ANN K. S.), An Account of the Tārikhi Qumm, 586-596; rev., 445.

Legends of Khotan and Nepal (John Brough), 333-9.

LFRoY (J.), Introduction à l'Étude des Anciens Codes Orientaux, 234.

LesLAU (WolF), Gafat Documents, 266 f. ; The Position of the Dialect of Curia Muria in Modern Soutb Arabic, 5-19.

Letters in Chinese prose, $776 \mathrm{f}$.

LETTS (MalCOLM), trans. and edit., The Pilgrimage of Arnold von Harf, $436 \mathrm{f}$.

Leveen (JACOB), An Eye-witness Account of the Expedition of the Florentines against Chios in 1599, 542-554.

LEwIs (B.), Ismā'ili Notes, 597-600.

Lexique Arabe-Français (Léon Bercher), $242 \mathrm{f}$.

Lilātilaka : A Sanskrit Tract on Malayalam Grammar and Poetics (John Brough), 148-162.

LIN Li-Kovang, edit. and trans., Dharmasamuccaya: Compendium de la Loi. 1re partie, 446-450.

LU (C. H.), Chinese Sentence Series. Parts II and III, 477.

Lushai, notes on the syllable structure of, 713-725.

\section{M}

Mahāsin al-majālis of Ibn al-Arif, notes on the, 524-532.

Makhzanol Asrär (trans., Gh. H. Darab), 441-5.

Malacea, the Malay founder of medieval, 726-9.

Malay Founder of Merieval Malacca, The (R. 0. Winstedt), 726-9.

Malay Herodotus, A (C. C. Brown), 730-6.

Mamlūk Egypt, an Ismā'ili oath formula from, $597 \mathrm{f}$.

Manichaean Cosmogony, A Sogdian Fragment of the, 306-318.

Mansabdāri System and the Mughul Army (Abdul Aziz), 473.

Manuel de Tshiluba (Kasayi, Congo Belge) (A. Burssens), 485.

Marathi word-palatograms and articulation, $861 \mathrm{f}$.

Martini (François), trans., Contes Populaires Inédits du Cambodge, $259 \mathrm{f}$.

Masani (M. R.), India's Constitution at Work, $470 \mathrm{f}$.

MAster (ALFred), Indo-Aryan and Dravidian III, 340-364; $A n$ Introduction to Telugu Grammar, 466 ; An Unpublished Fragment of Paišäcĭ, 659-667 ; rev., $255 \mathrm{f}$.

MatThews, The Rev. GoRdon, obituary of, 274.

Maulana Abul Kalam Azad (Mahadev Desai), 471.

Mecmatatu'n-naza'ir of 'Ömer B. Mezîd, index to the, $535 \mathrm{f}$.
Medieval Islam (G. E. von Grunebaum), $430 \mathrm{f}$.

Meinhof, Carl, obituary of, 493-6.

Memorials in Chinese prose, 774-6.

Métaphore dans le Coran, La (T. Sabbagh), $235 \mathrm{f}$.

$m i$ in Hruso, 191.

Middle Persian spells, 39-47.

Minorsky (V.), Gardīzī on India, 625-640 ; Tamim ibn Bahr's Journey to the Uyghurs, 275-305; Vis u Rämīn, a Parthian Romance, $20-35$; rev., 441-5.

Miracle of the Pearls, The (A. J. Arberry), 36-8.

Miscellaneous records in Chinese prose, $783 \mathrm{f}$.

mine, 68 .

"Mongol Atlas" of China, The (Walter Fuchs), 478 f.

Monosyllable in Szechuanese, The (N. C. Scott), 197-213.

Moss (CYRIL), Homily on the Nativity of our Lord by Severian, Bishop of Gabala, $555-566$.

Mugali (R. S.), The Heritage of Karnātaka, $255 \mathrm{f}$.

MUKerJee (RADHAKamaL), edit., Economic Problems of Modern India, Vol. II, 470.

Mundy (C. S.), Notes on Three Turkish Manuscripts, 533-541 ; rev., 440.

Mythes Astrals et Traditions Littéraires (H. Pernot), 242.

\section{$\mathbf{N}$}

Nagar (Shastri Murari LaL), edit., The Vikramānkkadevacarita : Mahākāvya, 461.

Nahlu 'ibari n-nahli (G. al-Shayyal), 432.

Nahwa at-ta'äu'un al-Arabì ('Umar Farrūkh), 241.

Nepal and Khotan, legends of, 333-9.

Nepalese Buddhist Rituals (John Brough), 668-676.

Nevâî, 'Alî Sîr, notes on, 536 f.

Nevspaper Chinese by the Inductive Method (H. G. Creel and Têng Ssŭ-Yü), $260 \mathrm{f}$.

Nga Hnit Yathi (Thahkin Nu), 475.

Nigeria, the unwritten literature of the Igbospeaking people of South-Eastern Nigeria, 838-846.

Nirod Bhushan Roy, edit., English Records of Maratha History, Poona Residency Correspondence, Vol. I1, $47 \mathrm{I}$.

Niya documents and Dardic, 332.

Note on an Illustrated Manuscript of the Jog-Bäshisht, A (J. V. S. Wilkinson), 692-4.

Note on Iron and the Plough in Early China (A. Waley), $803 \mathrm{f}$.

Notes on the Mahāsin al-majālis of Ibn al-'Añf (A. J. Arberry), 524-532.

Notes on Ptolemy (J. Ph. Vogel), $122 \mathrm{f}$.

Notes on the Syllable Structure of Lushai (Eugénie J. A. Henderson), 713-725.

Notes on Three Turkish Manuscripts (C. S. Mundy), 533-541.

O

o compensatorily lengthened in Sinhalese, 167.

Ogba Omọde (Olukęmi), 486 f. 
OGONLESI (J.S.), Ilera li õgùn orọ, $486 \mathrm{f}$.

OLuкюim, $Q g b a$ Omode, 486 f. ; Órọ Màjàgì, $486 \mathrm{f}$.

'Ómer B. Mezîd, index to the Mecmût'atu'nnazáir of, $535 \mathrm{f}$.

Orin Yoruba (J. O. Ajibọla), $486 \mathrm{f}$.

Òrò Màjàgì (Olukẹmi), $486 \mathrm{f}$.

Ossetic, 329-332.

Ounje ile Yoruba (J. O. Ajibọla and B. Șomade), $486 \mathrm{f}$.

Owe Yoruba (J. O. Ajibọla), 486 f.

\section{$\mathbf{P}$}

. $p$ final in Hruso, 188.

Padethayaza, $703 \mathrm{f}$.

Pages from the Kitāb al-Luma* (edit., A. J. Arberry), 428.

Paisācī, an unpublished fragment of, 659-667.

Pali Yathābhütam (W. Stede), 397 f.

Panipat, 1761 (T. S. Shejwalkar), 472 f.

Panjabi $p a b b=$ Avestic frabda-, 641-4.

Parthian amulet, A, 47-57.

Parthian ending -èndè $(h)$, The, 58-65.

Patil (Devendrakumar Rajaram), Cultural History from the Vàyu Purāna, $457 \mathrm{f}$.

PatTabmirama Shastri, edit., The Tautātitamatatilaka of Bhavadeva Bhatta. Part III, 462.

pāysa, 323-6.

Pearls, miracle of the, 36-8.

PeRnot (H.), Mythes Astrals et Traditions Littéraires, 242.

PhIIrss (C. H.), Clive in the English Political World, 1761-4, 695-702 ; rev., 468-471.

Phonology of the Sinhalese Inscriptions up to the end of the Tenth Century (P. B. F. Wijeratne), 163-183.

Pilgrimage of Amold von Harff, The (trans. and edit., Malcolm Letts), $436 \mathrm{f}$.

Pok NI, U, 708 f.

PoNNYA, U, 706.

Position of the Dialect of Curia Muria in Modern South Arabic, The (Wolf Leslau), 5-19.

Prefaces and Colophons in Chinese prose, $772 \mathrm{f}$.

Probleme der Indischen Religionsgeschichte (Wilhelm Koppers), $251 \mathrm{f}$.

Prose-poetry in Chinese prose, $785 \mathrm{f}$.

Ptolemy, Notes on, $122 \mathrm{f}$.

\section{Q}

Qizzll Qujaš, the Uzbek dialect of, 86-105.

\section{$\mathbf{R}$}

-r final in Hruso, 190.

RaBIN (ChamM), Arabic Reader, 438.

RaghubIr Sinh (Maharaj Kumar), edit., English Records of Maratha History. Poona Residency Correspondence, Vol. 9, $471 \mathrm{f}$.

Rājasthāna-Bhärati, Journal of the Sadul Rajasthani Research Institute, $252 \mathrm{f}$.

Readings in Traditional Chinese (edit., Chichen Wang), 261.

Recherches sur le Vocalisme, le Consonantisme, et la Formation des Racines en "Nostra. tique" (A. Cuny), 243.
Richard Hakluyt and his Successors, $257 \mathrm{f}$.

Rideout (J. K.), The Context of the Yüan

Tao and the Yüan Hsing, 403-8.

Rossi (ETtoke), Grammatica di Persiamo Moderno, con Esercizi, Vocabolarietti e Note di Metrica, $\mathbf{4 4 5}$.

Rowlands (E. C.), rev., $486 \mathrm{f}$.

RUdRA (A. B.), The Viceroy and GovernorGeneral of India, $468 \mathrm{f}$.

\section{$\mathbf{S}$}

$s$ initial, loss of in South Dravidian, 132-147.

$s$ and $\dot{s}$ - initial in Hruso, 191.

Sabbagh (T.), La Métaphore dans le Coran, $235 \mathrm{f}$.

Sabhaparvan, The (edit., Franklin Edgerton), $458 \mathrm{f}$.

Sadul Rajasthani Research Institute, Rājasthāna-Bhāratī 252 f.

Saho (Lakshmi Narayaxa), The Hill Tribes of Jeypore, 251.

saku, 68.

Salakènoi $=$ Sālà̀kāyana, 123.

Sañdeśa Rāsaka of Abdul Rahaman, The, edit., Śri Jina Vijaya Muni and Harivallabh Bhayani, $462 \mathrm{f}$.

Sangam Anthologies, The Avvai of the, 399402 .

Sanskrit rájas (T. Burrow), 645-651.

sāntäk, 69 .

Sarkar (Sir Jadunath), edit., English Records of Maratha History. Poona Residency Correspondence, Vol. 8, $471 \mathrm{f}$.

Al-Sayed al Baz Al-'Arini, edit., Book of al-muhtassib (Nihāyat al-rutba fi talab alhisba), 434.

SchUSTER (Sir George), India and Democracy, 468.

SCHÜTTE (Father JosePH), Il Cerimoniale per $i$ Missionari del Giappone, 482-4.

Scotr (N. C.), The Monosyllable in Szechuanese, 197-213; A Study in the Phonetics of Fijian, 737-752.

Secondary shortenings of vowels in Sinbalese, $167 \mathrm{f}$.

SEIN TiN, U, 709-712.

sekwe, 68.

Selections from the Deccan Commissioner's Files (Peshwa Daftar). Period of Transition (1818-1826) (edit., R. D. Choksey), 474.

Self and its Complications, The (W. Stede), 652-8.

Seven Princes, The (H. W. Bailey), 616-624.

Severian, Bishop of Gabala, homily on the nativity of our Lord by, 555-566.

ShaFer (RoBert), Hruso, 184-196.

aL-ShayYal (G.), edit., Nahlu 'ibari n'nahli, 432 .

SheJwalkar (T. S.), Panipat, 1761, 472 f.

Shellabear (W. G.), A Dictionary of Standard Malay (Malay-English), $476 \mathrm{f}$.

Short History of Transjordan, A (B. Toukan), 242.

Srmon (W.), A Beginner's Chinese-English Dictionary of the National Language (Gwoyeu), 481 f.; Bib 此' = Wey 侣'?, 789-802; Chinese Sentence Series. Parts II and III, 477 ; rev., $260 \mathrm{f}$. 
Sinhalese, compensatory lengthening of vowels in, 163-7; inscriptions, phonology of, 163183 ; secondary shortenings of vowels in, 167-9; "umlaut" in, 169-175; vowel assimilation in, 176-180; vowel contraction in, 181-3.

Smmir (Maraaret), Al-Ghazāli the Mystic, 237.

Sogdian ancient letters, date of the, 601-615.

Sogdian Fragment of the Manichaean Cosmogony, A (W. B. Henning), 306-318.

Sogdica (W. B. Henning), 244.

Șomade (B.), Ounje ile Yoruba, $486 \mathrm{f}$.

Spelling of African Place-Names on Maps, The (A. N. Tucker), 824-830.

ssänaumä, 327.

ssau, $327 \mathrm{f}$.

stänwo, 69.

STAPPERS (L.), rev., $267 \mathrm{f}$.

Stede (W.), The Self and its Complications, $652-8$.

Stewart (J. A.), A Burmese-English Dictionary. Part I, $258 \mathrm{f}$. ; Country Life in Burmese Literature, 703-712 ; rev., 259 f., 475.

Strateen (H. vaN), The Far East Must be Understood, 478.

STrauss (E.), Tōledhōth Hayyehüdhìm $B^{e}$ mişrayim Ve-süriyāh, $240 \mathrm{f}$.

Structure Grammaticale des Langues Dravidiennes (Jules Bloch), 253-5.

Studies in Biblical Law (David Daube), 438-440.

Studies in the Vocabulary of Tochariain (A. J. van Windekens), 67-70.

Study in the Phonetics of Fijian, A (N. C. Scott), 737-752.

Study in the Phonology of an Igbo Speaker, A (J. Carnochan), 4l 7-426.

Succession of Cognate Collaterals in Hindu Law, The (S. G. Vesey-FitzGerald), 677687.

Sudan Colloquial Aratic (J. S. Trimingham), 427.

Suma Oriental of Tomé Pires and the Book of Francisco Rodrigues, The (edit. and trans., Armando Cortesão), 256 f.

Swahili, foreign sounds in, 214-232.

SweETMan (J. WINDRow), Islam and Christian Theology. Part 1, Vol. 1, 435.

Syria, the tribes of, in the fourteenth and fifteenth centuries, 567-573.

Szechuanese, the monosyllable in, 197-213.

$\mathbf{T}$

t $t$ final in Hruso, 188.

Tableau des Racines Sémiliques (Arabe. Hébreu) (Carra de Vaux), 242.

Ta'lim al-muta'allim-Tariq al-ta'allum (trans., G. E. von Grunebaum and Theodora E. Abel), 429.

Tamim ibn Bahr's Journey to the Uyghurs (V. Minorsky), 275-305.

Târikhi Qumm, an account of the, 586-596.

Al-tasawwuf fil-Isläm (Omar A. Farrukh), $429 \mathrm{f}$.

Tautätitamatatilaka, The, Part III (Bhavadeva Bhatta) (edit., A. Chinnaswami Sastri and Pattabhirama Shastri), 462.
Telugu, syncope and aphæresis with compensation in, 340-6.

Tempels (P. Placied), Bantoe-Filosofie, $267 \mathrm{f}$. TÊng Ssư Yü, Newspaper Chinese by the Inductive Method, $260 \mathrm{f.}$; Translations of Text Selections and Exercises in Newspaper Chinese, 261.

Thahgin Nu, Nga Hnit Yathi, 475.

Theological Text, A (A. S. Tritton), 1-4.

Thomas (E. J.), rev., 457-462.

Thomas (F. W.), A Tibeto-Chinese Word-andPhrase Book, 753-769 ; rev., 446-453.

Thompson (M. S. H.), The Arvai of the Sangam Anthologies, 399-402.

Tibétain Littéraire, Grammaire du (Jacques Bacot), 450-3.

Tibeto-Chineze Word-and-Phrase Book, A (F. W. Thomas and L. Giles), 753-769.

T'ibi t'ire (S. I. Kalẹ), $486 \mathrm{f}$.

Tocharian, studies in the vocabulary of, 67-70; two notes on, $71 \mathrm{f}$.

Toghuzghuz, 285-296, 297 f., 301-4.

Töl'dhoth Hayyehüdhim Be-misrayim Ve. sūriyāh (E. Strauss), $240 \mathrm{f}$.

Topical Chinese Dictionary, A (Harry S. Aldrich), $479 \cdot \mathrm{f}$.

TOUKAN (B.), A Short History of Trans. jordan, 242 .

Translations of Text Selections and Exercises in Newspaper Chinese (H. G. Creel and Têng Ssư̆-Yü), 261.

Tribes of Syria in the Fourteenth and Fifteenth Centuries, The (A. S. Tritton), $567-573$.

Trimtraham (J. S.), Sudan Colloquial Arabic, 427.

Tritron (A. S.), A Theological Text, 1-4; The Tribes of Syria in the Fourteenth and Fifteenth Centuries, 567-573 ; rev., 234-244, 266 f., 427-438.

Ttaudägara-, 319-323.

Tucker (A. N.), Foreign Sounds in Swahili, 214-232; The Spelling of African PlaceNames on Maps, 824-830 ; rev., 486.

Tulu, 362 .

Tuqaj (Gabdulla), "The Forest-Demon." A Tatar poem of, 73-85.

Turkish-English Dictionary, A (H. C. Hony), 440.

TURNER (R. L.), Indo-Arica II, 641-4.

Twi, verbal tone patterns in, 833 .

Two Manichæan Magical Texts with an Excursus on The Parthian ending -êndè (W. B. Henning), 39-66.

Two Queens of Baghdad (Nabia Abbott), $427 \mathrm{f}$.

Two Tocharian Notes (A. J. van Windekens), $71 \mathrm{f}$.

\section{$\mathrm{U}$}

$\bar{u}$ compensatorily lengthened in Sinhalese, $166 \mathrm{f}$.

$-u$ final in Hruso, 187.

"Umlaut" in Sinhalese, 169-175.

Unpublished Fragment of Paisāci, An (Alfred Master), 659-667.

Unwritten Literature of the Igbo-Speaking People of South-Eastern Nigeria, The (M. M. Green), 838-846. 
Uyghurs, Tamim ibn Bahr's Journey to the, 275-305.

Uzbek Dialect of Qĩzil Qujaš, The (Stefan Wurm), 86-105.

\section{V}

V̄̄HID (AвDUL), Iqbal, His Art and Thought, $445 \mathrm{f}$.

Vâyu Purāna, Cultural History from the (Devendrakumar Rajaram Patil), $457 \mathrm{f}$.

Verbal Tone Patterns in West African Languages (Ida C. Ward), 831-7.

Vesey-FitzGerald (S. G.). See FitzGerald (S. G. Vesey-).

Viceroy and Governor-General of India, The (A. B. Rudra), $468 \mathrm{f}$.

Vikramānkkadevacarita : Mahākāvya, The (edit., Shastri Murari Lal Nagar), 461.

$V$ is $u$ Rāmīn, a Parthian Romance (V. Minorsky), 20-35.

Vocabulary of the Japanese Ports Lingo, The (F. J. Daniels), 805-823.

Vogel (J. Ph.), Notes on Ptolemy, $122 \mathrm{f}$.

Vowel-assimilation in Sinhalese, 176-180.

Vowel-contraction in Sinhalese, 181-3.

Voyage of Sir Henry Middleton to the Moluccas, 1604-6, The (edit., Sir William Foster), 476.

W

WaLEY (A,), Note on Iron and the Plough in Early China, $803 \mathrm{f}$.; rev., $261 \mathrm{f}$.

Wang (ChI-chen), edit., Readings in Traditional Chinese, 261.

WaRd (IDA C.), Verbal Tone Patterns in West African Languages, 831-7.

Weiss (L.), Al-Islām 'alā muftariq al-Turuq, $434 \mathrm{f}$.
West African languages, verbal tone patterns in, 831-7.

White (Edith M.), Bibliography of the Published Writings of Dr. L. D. Barnett, $497-523$.

WiJkratine (P. B. F.), Phonology of the Sinhalese Inscriptions up to the End of the Tenth Century, 163-183.

WILknnson (J. V. S.), A Note on an Illustrated Manuscript of the Jog-Bäshisht, 692-4; rev., 253.

WILSoN (J. A.), The Intellectual Adventure of Ancient Man, $431 \mathrm{f}$.

Winderens (A. J. vaN), Studies in the Vocabulary of Tocharian, 67-70; Two Tocharian Notes, $71 \mathrm{f}$.

WINSTEDT (R. O.), The Malay Founder of Medieval Malacca, 726-9 ; rev., 256-8, 476.

WINT (GUY), India and Democracy, 468.

Word-Palatograms and Articulation (J. R. Firth), 857-864.

Working Constitution in India, The (S. M. Bose), $470 \mathrm{f}$.

Worrell (WILlIAM), edit., Coptic Texts in the University of Michigan Collection, 262-6.

wrätal, 70.

Wdrm (Stefan), The Uzbek Dialect of Qizil Qujaš, 86-105.

\section{$\mathbf{Y}$}

-y - medial in Hruso, 191.

yathābhütam, $397 \mathrm{f}$.

Yoruba, verbal tone patterns in, $831 \mathrm{f}$, $834 \mathrm{f}$.

Yüan Hsing, the context of the Yüan Tao and the Yüan Hsing, 403-8.

Yüan Tao and the Yüan Hsing, the context of the, 403-8. 